\title{
Community Survey Report: Pokhara-Lekhnath, Ritthepani-27, Nepal
}

\author{
Pokharel D*, Shrestha J, Mamata KC, Thapa M, Ranabhat N, Dhakal R, Poudel R, Khadka S, \\ Phuyal S, Nepali S, Acharya S, Poudel S, Ghimire S \\ B.Sc. Nursing $2^{\text {nd }}$ year, College of Nursing Science, Gandaki Medical College, Lekhnath, Pokhara, Nepal
}

\section{Keywords \\ Community survey, Maternal health, Ritthepani.}

\section{Corresponding author \\ *Ms Durga Pokharel \\ B.Sc. Nursing $2^{\text {nd }}$ year \\ College of Nursing Science \\ Gandaki Medical College, Lekhnath, \\ Pokhara, Nepal \\ Email: munasilwal@hotmail.com}

\begin{abstract}
Community diagnosis is defined as a comprehensive assessment of the state of an entire community in relation to its social, economic, physical and biological environment ${ }^{1}$. It is a process of examining the patterns of disease or health status in the community in order to promote health, prevent disease and manage health services for the community people ${ }^{2}$.
\end{abstract}

As per the curriculum of Tribhuwan University, B.Sc. Nursing first year, we were provided an opportunity to fulfill the practicum of community health nursing in the assigned area Shanti Tole and Teentara Tole, Pokhara, Lekhnath, Ritthepani-27 from $18^{\text {th }}$ June to $14^{\text {th }}$ July 2017 . Total population of Ritthepani was 4529, male population was 2100 and female population was 2429. Each of the 13 students was assigned with 10 different families for community diagnosis in order to promote the health of the individual, family and community.

The main objective of community diagnosis was to find out the health related aspects and to provide preventive, promotive, curative and rehabilitative services to the individual and the community as a whole.

All the findings were presented among the key members of the community. On survey, total population of 130 houses was found 565, among them 296 were male population and 269 were female population. Sanitation of the community was inappropriate. People were not using the health facilities effectively so they were found suffering from different kinds of diseases most commonly gastritis. The common health seeking practice was going to governmental hospital and traditional healers.

\section{INTRODUCTION}

Community diagnosis is defined as a comprehensive assessment of the state of an entire community in relation to its social, economic, physical and biological environment ${ }^{1}$. It is a process of examining the patterns of disease or health status in the community in order to promote health, prevent disease and manage health services for the community people. It is based on collection and interpretation of the relevant data such as age, sex, population distribution, incidence and prevalence of important diseases of the area ${ }^{2}$.
As per the curriculum of Tribhuwan University, B.Sc. Nursing first year, we were provided an opportunity to fulfill the practicum of community health nursing in the assigned area Shanti Tole and Teentara Tole, Pokhara Lekhnath, Ritthepani-27 from 18 ${ }^{\text {th }}$ June to $14^{\text {th }}$ July 2017. Total population of Ritthepani was 4529 , male population was 2100 and female population was 2429. Each of the 13 students was assigned with 10 different families for community diagnosis in order to promote the health of the individual, family and community. 


\section{OBJECTIVES OF THE FIELD VISIT}

The main objective of community diagnosis was to find out the health related aspects and to provide preventive, promotive, curative and rehabilitative services to the individual and the community as a whole.

- To identify health need, problems and resources in defined areas population

- To carry out community diagnosis in the assigned community i.e. Pokhara-Lekhnath, Rithepani-27

- To communicate effectively with all concerned in providing client-centered care

- To prepare a list of existing facilities in the community concerning environmental sanitation

- To find out the services provided by the selected health related institutions through the direct contact with the community people

- To apply the epidemiological approaches in solving the identified problems through health action and exhibition programs

- To carry out the responsibilities of a community health nurse in the health promotion of the community people through health teaching and environmental approaches

Table 1: Plan of action

\begin{tabular}{|c|c|c|}
\hline Date & Program & Place \\
\hline $18^{\text {th }}$ June $-20^{\text {th }}$ June, 2017 & Tool orientation & GMC College Premises \\
\hline $18^{\text {th }}$ June $-25^{\text {th }} J u n e, 2017$ & Community orientation & Community \\
\hline $18^{\text {th }} J$ June $-30^{\text {th }} J$ June, 2017 & Community map & College and community \\
\hline $21^{\text {st }}$ June - $30^{\text {th }}$ June, 2017 & Data collection & Community \\
\hline $2^{\text {nd }}$ July - $7^{\text {th }} J u l y, 2017$ & $\begin{array}{l}\text { Data analysis and inter- } \\
\text { pretation }\end{array}$ & Community \\
\hline $20^{\text {th }}$ June $-5^{\text {th }}$ July, 2017 & Home visiting & Community \\
\hline $22^{\text {nd }}$ June $-11^{\text {th }} J u l y, 2017$ & Health teaching & Community \\
\hline $7^{\text {th }}$ July, 2017 & Data presentation & Community \\
\hline $9^{\text {th }}$ July, 2017 & Health action & Community \\
\hline $12^{\text {th }}$ July - $14^{\text {th }}$ July, 2017 & Follow up & Community \\
\hline $13^{\text {th }}$ July - $14^{\text {th }}$ July, 2017 & Evaluation & Community \\
\hline
\end{tabular}

\section{RESULTS}

Table 2: Demographic variables

\begin{tabular}{|c|c|c|}
\hline Variables & Frequency (f) & Percentage (\%) \\
\hline \multicolumn{3}{|l|}{ 1. Gender } \\
\hline Males & 296 & $52 \%$ \\
\hline Females & 269 & $48 \%$ \\
\hline \multicolumn{3}{|l|}{ 2. Types of family } \\
\hline Nuclear & 87 & $67 \%$ \\
\hline Extended & 43 & $33 \%$ \\
\hline \multicolumn{3}{|l|}{ 3. Religion } \\
\hline Hindu & 377 & $67 \%$ \\
\hline Buddhism & 138 & $24 \%$ \\
\hline Christian & 50 & $9 \%$ \\
\hline \multicolumn{3}{|l|}{ 4. Caste } \\
\hline Upper caste group & 21 & $16.5 \%$ \\
\hline janajati & 54 & $41.5 \%$ \\
\hline Dalit & 55 & $42 \%$ \\
\hline \multicolumn{3}{|l|}{ 5. Types of houses } \\
\hline Kachha & 25 & $19 \%$ \\
\hline Pukka & 105 & $81 \%$ \\
\hline \multicolumn{3}{|l|}{ 6. Ventilation } \\
\hline Well ventilation & 53 & $41 \%$ \\
\hline Poorly ventilation & 77 & $59 \%$ \\
\hline \multicolumn{3}{|l|}{ 7.Latrine } \\
\hline Water sealed latrine & 122 & $94 \%$ \\
\hline Bore holelatrine & 8 & $6 \%$ \\
\hline \multicolumn{3}{|l|}{ 8. Drainage system } \\
\hline Closed & 15 & $11.5 \%$ \\
\hline Open & 115 & $88.5 \%$ \\
\hline \multicolumn{3}{|l|}{$\begin{array}{l}\text { 9. Types of refuse } \\
\text { disposal }\end{array}$} \\
\hline Burning & 52 & $40 \%$ \\
\hline Composting & 9 & $7 \%$ \\
\hline Burning and composting & 28 & $22 \%$ \\
\hline Throwing & 42 & $32 \%$ \\
\hline \multicolumn{3}{|l|}{ 10. Types of kitcHen } \\
\hline Separate & 95 & $73 \%$ \\
\hline Attached & 35 & $27 \%$ \\
\hline \multicolumn{3}{|l|}{ 11. Drinking water } \\
\hline Public tap & 110 & $85 \%$ \\
\hline Spring & 13 & $10 \%$ \\
\hline Boring water & 7 & $5 \%$ \\
\hline
\end{tabular}

In the data depicted in Table 2 shows that majority (52\%) of the respondents were male population and remaining $(48 \%)$ were female population thus the sex ratio was 1.1 : 1 male and female respectively. The dependency rate was $(57 \%)$ and the literacy rate was (77\%). Similarly, more than half $(67 \%)$ of the family lived in nuclear family. Regarding religion, more than half $(67 \%)$ of the respondents were Hindus, 24\% were Buddhist and 9\% were Christian. With regards to caste, minority (16.5\%) of the respondents were of upper caste group. Beside these, majority $(81 \%)$ of the people live in pukka type of house. Furthermore, less than half (41\%) of the houses were well ventilated and majority (94\%) of the families were found to use water sealed latrine. In case 
of drainage system, minority (11.5\%) of the families used closed drainage system and minority (7\%) of the families used composting type of refuse disposal. Regarding types of kitchen, more than half (73\%) of the families used separate kitchen. Similarly, majority (85\%) of the families were drinking water from public tap.

Fig 1: Maternal Health on Pokhara-Lekhnath, Ritthepani -27 (Eligible couple $=132$ )

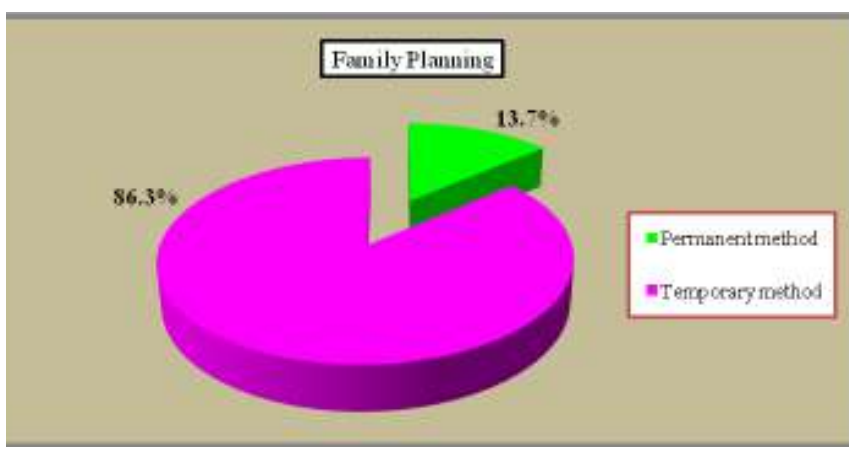

From the above pie-chart it is illustrated that among 132 eligible couples, majority $(86.3 \%)$ of them were using temporary method of family planning such as dipoprovera, oral pills, condoms, Intra-uterine contraceptive devices and remaining (13.7\%) were using permanent method.

More than half $(75 \%)$ of the pregnant women have received antenatal care including tetanus toxoid from the respected health care institutions.

The data of current morbidity revealed that people are suffering from different diseases like back ache, sinusitis, leg pain, common cold, diarrhea, fever with the percentage of $35 \%$, then $28 \%$ from gastritis, $17 \%$ from hypertension, $11 \%$ from headache, six percent from diabetes and remaining (Three percent) from asthma. In case of health seeking practice, most of the people (43\%) go to governmental hospital and traditional healers.

Among 130 different houses, vital events i.e. birth, death, migration and marriage took place in only 15 houses with the more than half $60 \%$ of birth and $20 \%, 13.3 \%, 6.7 \%$ of marriage, migration and death respectively.

On the day of health action all the key members from the community, faculties from the college and community people were invited and the program was conducted in formal manner. Data presentation was done successfully. As a health action, drama on the theme of difference between the educated family and uneducated family along with early marriage, alcoholism and its consequences was conducted. Nutritional exhibition was also carried out effectively along with real articles.

\section{Acknowledgement}

We are extremely grateful towards whole GMC family for providing community as well as facilities required for the field visit. This wouldn't have been possible without the continuous support and guidance by our coordinator Ms. Muna Silwal. Likewise, we are thankful to our teachers Ms. Rajmi Gurung, Ms. Ashmita Gurung, Ms. Indu Sah, and Ms.Dipti Koirala who helped us throughout the project. Likewise we would like to thank to our respected seniors Ms. Anju Lamichhane, Ms. Asmita Devkota, Ms. Binita Thakuri, Ms. Durga Shahi and Ms. Krishma Magar. Moreover, we would also like to thank the ward president, community leaders, female community health volunteers as well as all the community people for providing us the required information and making this project a successful one. How can we ever miss to thank the store department as well as the Information Technology Department who provided us with all the required supply. At last but not the least, we would like to thank our dear helper Ms. Dilkumari Thapa for aiding us in this project.

\section{REFERENCES}

1. K. Park. Park's Textbook of Preventive and Social Medicine, 22nd edition. Banarsidas publishers, Jabalpur (MP), India. 2013.

2. Tuitui R. Textbook of Community Health Nursing. $1^{\text {st }}$ Edition. Vidhyarthi Prakashan Pvt. Ltd. Kamalpokhari, Kathmandu. 2063.

3. Basvanthappa B.T. Community Health Nursing. Jaypee Brothers Medical Publishers Pvt. Ltd. New Delhi. India. 1988.

4. Ghimire B. Textbook of Community Health Nursing. $4^{\text {th }}$ Edition. Heritage Publishers and Distributors P. Ltd. Bhotahity, Kathmandu. Nepal.2015. 